\title{
The New Egypt: Socio-political Dynamics and the Prospects of the Transition to Democracy
}

\author{
Mohammed M. Hasanen, Ph.D \\ (Corresponding Author)
}

\author{
Humanities and Social Sciences Department \\ Gulf University for Science and Technology, Kuwait \\ Email:Hasanen.m@gust.edu.kw \\ Mohammed Nuruzzaman Ph.D \\ Humanities and Social Sciences Department, \\ Gulf University for Science and Technology, Kuwait \\ Email: zamanuofa@yahoo.ca
}

Doi: 10.5901/mjss.2013.v4n4p137

\begin{abstract}
The February 11, 2011 victory of pro-democracy forces has ushered in great hopes for actual political and social changes in Egypt. The military-led long authoritarian rule has come to an end, and Egypt has stepped in a new era of transition to democracy. This paper probes the prospects of democratic transformation in Egypt in light of its unique pre and postrevolutionary social and political dynamics. It argues that Egypt's transition to democracy largely depends on the chemistry of post-revolutionary socio-political dynamics and how this dynamics keeps unfolding.
\end{abstract}

Key words: Egypt; authoritarian rule; democratic revolution; socio-political dynamics; democratic transition.

"In a revolution, as in a novel, the most difficult part to invent is the end". Alexis de Tocqueville

\section{Introduction}

February 11, 2011, set a new milestone in Egyptian history. The pro-democracy forces won a historic victory that day after toppling the long entrenched Hosni Mubarak dictatorship. The democratic revolution has ushered in new hopes for the Egyptians to shape the future of their country. Their agenda is to build Egypt anew by reorienting its political system and socialorder. This post-revolutionary task is definitely more difficult than the revolution itself. Egyptian society has been under military-led authoritarian rule for the entire post-independence period and has had minimal exposure to democratic norms and practices. Furthermore, a number of daunting political and socio-economic issues are proving persistent challenges to any successful transition to democracy. Notable among these are the interests of the youth groups who were the driving force behind the revolution, the representation of religious groups, and above all the power and influence of the military. At the time of writing, a constitutional referendum is taking place amidst debate, protest, and counter-protest by these various groups. This is sure to be just one of many tests/realignments of the new political power dynamic.The developments since the 2011 Revolution frame a fresh perspective for an analysis of Egypt's post-1952 socio-political history, informing a clearer understanding of the emergent landscape.

This paper focuses on the prospects of post-revolutionary democratic political transformation in Egypt. We argue that the success of Egypt's transition to democracy will be largely determined by its unique social and political dynamics, long shaped by military-led authoritarian rule, but significantly altered by the pro-democracy revolution. The toppling of the powerful traditional post-1952 social and political forces has given the previously oppressed groups of forces students, unemployed youths, workers, religious groups, and other pro-democracy elements- an upper hand in postFebruary 11 Egyptian politics. This major political change sets a new phase of social and political dynamics for a democratic Egypt, and much of Egypt's democratic future depends on how this phase unfolds.

Following an analysis of the history of authoritarian rule in the Arab world generally (in Section 2), the paper develops this argument in the four subsequent, interrelated sections. Section 3 discusses Egypt's authoritarian tradition 
and practices since 1952, focusing on the politics of the past three governments of Gamal Abdel Nasser, Anwar El-Sadat and Hosni Mubarak to highlight how authoritarian rules and practices were gradually imposed, shrinking the space for democratic rights and voices. Section 4 analyzes the social and political underpinnings of Egyptian society and politics over the past decades. Section 5, on the basis of the preceding analysis, discusses the emergence of the opposing social and political forces in the months and years leading to the February 11 democratic revolution. Section 6 assesses the prospects for democratic transition in light of the discussions and analysis presented in the foregoing sections. Finally, Section 7 summarizes and offers conclusions based on the evidence and arguments presented in this paper.

\section{The Long Authoritarian Rule in the Arab World}

Arab authoritarian regimes are notorious for their longevity, which has often drawn the Middle East into debates within the fields of social science about the legacies of political institutions and leadership styles. These regimes are characterized, with a few exceptions, by unchecked personal rule that relies on a narrow social base, often including its loyal clients such as friends, colleagues and clans. The leaders have extensive discretionary powers that spawn widespread corruption at all levels of society, blurring the distinction between the state and the regime. A certain degree of political pluralism is allowed within both the regime coalition and the legal opposition, while the populace as a whole remains politically marginalized or, at the most, mobilized along communal or clientele lines.

A few of the Arab authoritarian regimes, such as Egypt, Syria, Tunisia, Yemen, etc., are nominally considered republics. In contrast to the Gulf Arab monarchies, where power has long been transferred through hereditary succession, the so-called Arab republics have been in the process of developing 'father-to-son' political succession models. In the Arab republics, for the last two or more decades, the ruling family members have been acting as medieval barons, with unfettered command and control over state institutions. These ruling families have developed mechanisms for settling family disputes, especially over succession and sharing of benefits. However, family rule in the Arab world is viewed as compatible with Arab political norms and has stood and still stands as a source of political legitimacy. For example, Bernard (2002) writes that hereditary succession and dynastic principle are deep-rooted and universal practices in the Islamic Middle East. To a large extent, this explains the continuity of even pre-Islamic types of rule up to the second half of the twentieth century.

European colonial penetrations into the Arab Middle East in the first quarter of the twentieth century deeply affected its historical processes of regime building, state formation, and nation crafting. The withdrawal of Ottoman rule from the Arab region at the end of the First World War changed the political map of the area. Britain and France entered and divided the Arab territories between them. Only Saudi Arabia survived these colonial divisions. London and Paris worked to draw new borders in the region, unsuccessfully tried to establish political systems similar to those in France and Britain at the time, and imposed on these countries the Western concepts of state and nation, which had been previously absent in the Arab world. It was only after 1919 that state boundaries, nationalities, etc., emerged as impediments to the free movements of individuals or tribes across Arab territories.

The colonial powers withdrew from the region mostly after the Second World War; however, they left behind arbitrarily drawn territorial units called 'states'. A new class of Arab monarchical rulers, who collaborated with the colonial British and French governments, emerged to lead the new states and their peoples. In the 1950s and 1960s, monarchical rules in Egypt, Iraq, Libya, and Yemen came to an end, and they were declared republics by the military leaders who had captured political power through successful military coups. In Morocco and Jordan, military coups were attempted, but monarchies survived. Leaders in the newly declared republics allowed constitutional structures and processes in which the people were supposed to have the upper hand; however, this did not happen in reality. The military leaders gradually established a political system based on their unchallenged and unrestrained powers. Opposition political forces were minimally tolerated, growth of functional political institutions was retarded, and people were consistently denied their basic political rights. Steadily, these Arab republics became de facto autocratic or authoritarian states. Under these regimes, neither energized civil society nor democratic institutions developed.

\section{The Regimes of Nasser, El-Sadat, and Mubarak}

Egypt was declared a republic in 1952 after General Muhammad Najeeb and the "Free Officers" had overthrown the constitutional monarchy under King Farouk. The army-led Revolutionary Command Council (RCC) declared the 1923 Constitution null and void and banned all political parties. To protect the Egyptian revolution, the RCC declared a state of emergency that has been in place for the last six decades. In 1981, after Anwar Sadat was assassinated, an emergency 
law was enacted - thereafter, parliament has voted consistently every three years to renew this anti-democratic emergency law. Consequently, modern Egyptian political history has been one of military authoritarian rules.

Post-1952, all Egyptian presidents have come from the military establishment, and each president brought with him a unique personality and individual leadership style: what Weber and Easton (Hudson, 1977) variously described as "revolutionary legitimacy" or "charismatic personalities." Their legitimacy was based simply on the fact that they had participated in their nation's independence struggle or revolutionary coup, and/or had forceful personalities (Hudson, 1977). Egypt has not enjoyed the benefit of real free elections and the development of democratic institutions under its past three presidents (Gamal Abdel-Nasser, Anwar El-Sadat, and Hosni Mubarak). All three used repressive measures to maintain their respective regimes.

The recently toppled President Hosni Mubarak succeeded Sadat in 1981. General Mubarak came from the Air Force but he was not a member of the original 1952 freedom-fighting "Free Officers". Although President Mubarak did not have the charisma of former Presidents Nasser and Sadat, or even their ideological backgrounds or political experiences, he succeeded in maintaining his regime for about thirty years. Even a few months before the 2011 Revolution, some people believed that Mubarak's political agenda would be sustained after his personal departure from the political scene.

In contrast to Nasser, who depended on his ability to lead and motivate the Egyptian masses, or Sadat, who depended more on the National Democratic Party (NDP) to drum up support for his policies, former President Mubarak ran his political regime using an approach of gradual political development. He successfully capitalized on Sadat's economic and political polices and, at the same time, developed a "clientele system" to generate support for his regime. Mubarak thereby built what can be called an unbreakable "iron triangle" by granting special favors and consideration to specific individuals or groups. The iron triangle, explained in detailing the next section, was forged in combination with three sets of powerful social and political forces: the dominant ruling political party (the NDP), influential business elites, often dubbed crony capitalists, and the military establishment. Each side of this triangle had its own interests in propping up the Mubarak regime; thus, they developed a kind of symbiotic relationship.

In his early years in power, Mubarak, possessing little in the way of concrete ideology, focused on strengthening the NDP. The average Egyptians were attracted to the NDP by its lavish bestowment of wasta (favoritism). The key link in this process was the patron-client relationship. Similar to Hafiz al-Assad of Syria, Mubarak was the supreme patron, and all major actors in the Egyptian political system were his clients. They relied on him to get their positions, and, in return, their support ensured his political survival. By relying on the NDP, Mubarak was able to ensure the passage of all his political decisions and public policies. At the same time, he marginalized and weakened the other political parties and groups by imposing countless administrative laws and electoral hurdles. As a result, opposition political parties did not have a real presence or influence on the decision-making process of the country. Their representation in the Egyptian Parliament was very limited and mostly ineffective. The NDP maintained an absolute majority in the Egyptian parliament throughout the Mubarak era. In the last parliamentary elections under Mubarak in 2010, the NDP won $97 \%$ of the seats, which upset the common people in Egypt.

\section{Underlying Social and Political Dynamics in Egypt Since 1952}

Principal trends in Egypt's social and political dynamics originate from the authoritarian rules and practices discussed above. In a rather conventional way, this dynamic is epitomized by three binary divisions: people versus authoritarianism (or the struggle for democracy), Islamic versus secular political forces, and the rich versus the poor. For example, Palmer (2007) mentions three important factors that characterize Egyptian political dynamics: the overwhelming presence of Islam, which favors Islamic rule and practices; mass political passivity created by long foreign domination and repressive authoritarian rules; and a level distrust between people and the government that has resulted in a sense of mass alienation from the state. Egypt, as a result, is yet to come close to developing the sense of a political community that played a significant role in European and North American political development.

Each of these binary divisions has a role to play in explaining modern Egyptian politics and society. After all, the policies and programs of the past three presidents, largely framed by these binary divisions, sculpted the socio-political landscape of contemporary Egypt. However, it is difficult to explain Egyptian political and social dynamics by looking at these three binary divisions or the evolving patterns of its political culture alone. A major critique of the binary divisions is that they are mostly based on surface explanations of Egyptian society and politics, and they fail to identify and consider the actual forces underpinning these elements. The binary lenses are also unable to explain when status quo-oriented forces may favor change, as noted in the shift of the Egyptian military's support away from Hosni Mubarak to the prodemocracy forces in the final hours of the January 25,2011 , revolution. 
Perhaps a better way to explain Egyptian social and political dynamics is to look at the forces that control the state and those that are controlled by it. The former category includes the authoritarian rulers and their powerful supporters (like the military, the crony capitalists, and the political beneficiaries grouped under the now banned NDP). The latter category of forces primarily consists of the anti-status quo forces -the Egyptian youth bulge across the political and social spectrum, civil society organizations, workers (in both public and private sectors), women, and the student community. The conflicts between these two opposing sets of forces have been developing since the Nasser years; it is only under the Mubarak regime that they burst into a popular uprising, resulting in the recent dramatic change in the status quo.

Post-1952, the status quo-oriented forces gradually crystallized and, under Hosni Mubarak, they took a concrete shape in the form of an iron triangle, briefly referred to above. The iron triangle was marked by three important characteristics -co-dependency, interest convergence, and non-democratic values. Together, they perpetuated the long authoritarian regime of Hosni Mubarak. In the few paragraphs below, we further describe the basics of the iron triangle.

The first side of the triangle, co-dependency, refers mainly to the relationship between the Mubarak regime and the NDP. The NDP has been the only national-level political party in Egypt since the time of President Anwar El-Sadat until the recent uprising. No strong opposition political party developed or had been allowed to develop during that time. Opposition political figures were either controlled or stopped (by means of machinations) from putting up any effective challenge to the Mubarak regime (Brownlee, 2007). In this prevailing political context, the NDP performed a few important roles. First, it was the officially recognized political link between the Mubarak regime and the Egyptian people. An elaborate NDP party structure connected people from villages and neighborhoods up to the national level. Common Egyptians saw it as a wasta to extract benefits like preferential treatment or access to public sector jobs controlled by the ruling political elites. Secondly, the NDP ensured a majority of seats in the parliament for the regime in all elections held under Hosni Mubarak, thereby contributing to regime stability and survival.

In late 1990s, a new generation of regime guards came to the fore, working for Mubarak's younger son, Gamal Mubarak. Gamal Mubarak graduated from the American University in Cairo early 1990s and then worked as an investment banker for the Bank of America in both Cairo and London. In 2000, he was appointed to the General Secretariat of the NDP. In September 2002, two years after his political incarnation, Gamal became head of the newly formed Policies Committee in the NDP, which was, in fact, a group of young supporters of the regime open to experiment political as well as economic reforms. The older Mubarak was actually grooming Gamal to succeed him in power; however, he had no strong support in this from the powerful military establishment (Weaver, 2003).

The fragmented nature of the opposition political parties was also responsible for the dominance of the NDP. During the 2005 presidential election, the government recognized some fifteen legal political parties, excluding the Muslim Brotherhood; however, these parties were so diverse in terms of political goals and ideological perspectives that they failed to mount any significant opposition to the Mubarak regime. Stacher (2004b, p. 219)contends that the opposition parties preferred not to bridge ideological differences in order to win benefits. Some parties even viewed opposition unity as an obstacle to sharing power with the government. It worth noting that this policy of the opposition parties was actively encouraged by the government

The second side of the triangle, interest convergence, was represented by a well-built and powerful business group. This process actually started after Sadat's introduction of infitah, an open door policy to pursue national development through private entrepreneurship. Under Nasser, Egypt had embarked on a course of national development, with the state playing the leadership role to develop the infrastructure and heavy industries while the private sector was left undisturbed to lead agriculture, electricity and water, banking, trade, and transport. The capitalist class had limited economic opportunities, and the revolutionary tone of the Nasser government, particularly the radical land reforms that considerably weakened the landed aristocracy, spread a sense of panic among them (Aoude, 1994).

Sadat's infitah reversed Nasser's development policies and paved the way for Egypt's integration in the capitalist global economy. The state under Sadat gradually embraced the economic reforms prescribed by the World Bank and the IMF. The annual $\$ 2$ billion aid package Egypt was promised by the US for signing the 1979 Camp David Peace Accords with Israel put extra stress on the Egyptian state. A shift from Nasser's policies was gradually taking place. State subsidies for food, housing, education, and medical services, which Nasser had provided for free to all Egyptians, had already forced Egypt to run deep into debt.

During Hosni Mubarak's long rule, the NDP-supported capitalist business class came full circle. In the economic policy realm, Mubarak simply kept carrying out what Sadat had started. The Mubarak regime was known for its unbridled economic reforms, particularly the privatization of state-owned enterprises and corporations. Gamal Mubarak led a band of private entrepreneurs and sold out most state corporations to private Egyptian businessmen and investors from Brazil, China, Russia, the US, and the Gulf Arab countries. This business class got unprecedented access to state resources and maximized their fortunes, this, in turn, increased the economic and political power of the Mubarak régime while 
widening the gap between the rich and the poor. The opposition parties, media, and other political movements talked almost on a daily basis about one or more members of this group being involved in monopolies, corruption, and other scandals, while drawing little or no government response. The leaders of this group were well-connected to the ruling party, and the government had no interest in looking into the accusations of the opposition groups (King, 2007). The loyalty of this group of crony capitalists went to the regime, which assured its privileges and immunity.

The military was the third concrete pillar of the iron triangle to maintain Mubarak régime and in indirect way enforcing the non-democratic values element. Ensuring the security of the Mubarak regime was its primary responsibility. Traditionally, the military has enjoyed a privileged position in Egyptian society. Two specific factors have made the military an institution of national pride. First, it was the real force behind the 1952 revolution, which proved a catalyst for Egypt's break from its feudal past to emerge as modern nation and engage in state-building processes. Secondly, the military played a glorious role, despite defeats in the 1948 and 1967 wars against Israel, in the long Arab-Israeli conflict. The 1973 war against Israel did not result in a victory for Egypt either; however, it succeeded in inflicting heavy damages on the Israeli military, which forced the Israeli leaders to negotiate the 1979 Camp David Accord with the Egyptians.

The Egyptians have honored the military, in turn, by not objecting to the appointments of high ranking or retired military officials to top political or diplomatic positions of the state. Mubarak, in order to neutralize any military threats to his rule or to placate ambitious military officers, routinely placed the top brass of the military in important positions in the government as well as the private sector. Many ambassadors, governors, and advisors to the president were drawn from the military. Despite a decrease in the military's influence and prestige after the 1979 peace treaty with Israel, young Egyptians are motivated to join the military for job security and to avoid the escalating unemployment in the country.

The iron triangle of political, business, and military elites no doubt worked well for the continuation of the Mubarak regime; the solidarity of the triangle was sufficient to avert the fall or immediate fragmentations of the regime in the 1990s that some intelligence and academic sources had predicted (Alterman, 2000a, p. 108). However, the Mubarak regime'snarrowly focused socio-economic policies and political strategies engendered a rising tide of opposing political and social groups, which threatened the very foundation of the regime and finally brought it down in February, 2011. We move to a brief discussion of the coalition of opposing social and political forces below.

\section{Coalition of Opposing Social and Political Forces}

The anti-Mubarak political and social forces represent a set of diverse groups, covering broad political spectra, from left to right and from secular to religious. The secular April 6 Youth Movement, the labor unions, the Islamic-oriented Muslim Brotherhood youth front, a few timid political parties (including the unofficial largest opposition party - the Muslim Brotherhood), the feminist groups, and hundreds of non-governmental organizations (NGOs) were main elements of the anti-Mubarak coalition. However, these forces did not coalesce until the pro-democracy movements finally kicked off by mid-February 2011. The set of common goals that tied them together were the desire to get rid of authoritarian excesses and to introduce democracy to ensure political equality and social and economic justice for all Egyptians.

Many of these opposition political and social groups emerged in the two to three years prior to the 2011 Revolution. The April 6 Youth Movement emerged in 2008, and its support base includes recruits from educational institutions, industrial belts and unemployed youths from major Egyptian cities. The powerful labor movements, reminiscent of the anti-colonial struggles against the British in the 1930s to 1950s, marked their presences through national strikes and sitins in 2009 and 2010. At the peak of anti-Mubarak protests, the labor unions from across Egypt formed the Independent Trade Union Federation on January 30, 2011. Even the people in the countryside rose up to protest the government's land reform policies that threatened to evict them to reintroduce the consolidated land ownership that Nasser had effectively dismantled after the 1952 revolution (Amr, 2011a). The struggle against Mubarak further accelerated with enthusiastic participation by pro-democracy and change-oriented NGOs. In Egypt, as in other poor countries, hundreds of NGOs operate, and these NGOs supplement the government role to provide assistance and services to poor and needy social classes. Once mass protests broke out against the government, many of the NGOs mobilized the poor people in support of the revolution.

It is important to note that the growth of Egyptian trade unions was expedited by the privatization policy of the Mubarak government. The primary interests of the trade unions are to protect workers' rights and Egypt's manufacturing base from being gradually taken over by foreign investors. In the few years preceding the 2011 revolution, the Chinese, the Russians, the Central Asian republics, and the Gulf Arabs have invested in almost every sector of the Egyptian economy, creating job opportunities for tens of thousands of Egyptians. These workers were not economically marginalized; however, they were deprived of their rights, which motivated them to join forceswith public and private 
sectors factory workers' unions. The mobilization process leading to the uprising against Hosni Mubarak was greatly aided by these workers (Amr, 2011b).

The support from the army and the national capitalist class gave the coalitional major political boost at the critical hour of the revolution. The military establishment, as noted above, was part and parcel of the Mubarak regime; however, once it sided with the pro-democracy protesters, the iron triangle began to crumble. Two possible factors that led the military to withdraw support from the Mubarak regime can be mentioned here. First, in his long thirty-year rule, former President Mubarak did not nominate a successor, but was grooming his son Gamal Mubarak to succeed him in power. Egypt's armed forces detested Mubarak's efforts to establish a new dynastic rule. High-ranking military officials were averse to the idea of dynastic succession, instead favoring rule by a strong military man. Gamal Mubarak was not a member of the military establishment. Secondly, the Egyptian army officers were also outraged by Gamal Mubarak's neoliberal development strategy, which threatened their multi-billion dollar industry in construction, gated cities in the desert, real estate business, tourist resorts, and hotels built for medium income and rich people from around the globe. According to one source, by the end of the 1990s, nearly half of Egypt's manufacturing capabilities were controlled by the army (Alterman, 2000b, p 114). The desire to protect this vast economic interest probably drove the army to shift loyalty from a waning Mubarak and side with the rising tide of the pro-democracy forces.

Likewise, Egypt's national capitalist class decided to support the mass protests against Hosni Mubarak. This class upholds the view that Egypt's economic development must be rooted in Egyptian soil and that the leadership role should be provided by its own capitalist class. It was opposed to the plundering of national resources by the group of international capitalist barons led by Gamal Mubarak and resented rampant corruption among Mubarak's inner circle. The national capitalist class was seeking to maintain and enhance autonomy in national development policies, regarding the transfer of state corporations to foreign capitalists as a "sell out" of Egyptian interests (Amr, 2011a). These concerns brought this class to identify itself with the common Egyptians who risked their lives to oust Mubarak.

This brief analysis on the anti-Mubarak coalition of political and social forces was raged by three important points. The traditional elitists structure -what we have characterized as the iron triangle - facilitated the emergence of a new set of social and political forces. However, this new set of forces failed to control state power during the transitional period, which lasted in June 2012, while street protests in major cities were capable of exerting tremendous influence on the military-led authority. Secondly, although Mubarak's traditional political elites were weakened by the democratic revolution and post-revolution developments, they are not completely out. The repressive security apparatus, particularly the police force and the State Security Investigation organization, though reformed, have not been abolished altogether. The pro-Mubarak forces are working to abort the revolution. Finally, even as Egypt has started to build its own political institutions and elected a new president, the society is divided in general into two groups, as evidenced in polarization engendered by the constitutional referendum of December 2012. The first one includes all Islamic political parties, overwhelmingly in favor of the draft constitution. On the other side, the liberal political parties have established a strong front to oppose the Islamists. It is in this context that the democratic prospects of Egypt should be assessed.

\section{Assessing the Prospects for Transition to Democracy}

Two crucial questions concern Egypt's prospects for democratic transition: Will Egypt finally is able to democratize itself? How transformative will the changes be in post-revolutionary Egypt in terms of laying the foundation for democratic norms, values, and practices? The pro-democracy forces are fired with an unending democratic zeal, though Egyptian historical experiences do not bode well for them. There are reasons for both hope and despair.

The 2011 revolution for political and social change is the fourth significant milestone in Egypt's history. The previous three historic events - the Orabi protest movement of 1879-82, the 1919 uprising, and the 1952 military-led revolution, inspired millions of Egyptians to rise up against the British and their local collaborators to liberate Egypt and bring about real socio-economic and political changes. Of the four events, the Orabi movement and the 1952 revolution were carried out by army officers; both succeeded in institutionalizing primarily non-political reforms. What was noticeably lacking in the aftermaths of 1882 and 1952was political reform? In both cases, the rulers kept the political system restricted, denying the common Egyptians the right to participate in the political life of the country (Said, 2011).

The 1919 mass uprising for independence from the British and the 2011 revolution are the outcomes of gigantic mass movements, with the ultimate objective being political change. The 1919 uprising brought provisional independence for Egypt: the Egyptians got a new constitution drafted in 1923, and a parliamentary system of government in 1924. The British government, however, remained in effective control. The actual long-term outcomes of the 2011 revolution remain far from certain. 
Does the current revolution portend hopes for real democratic political changes in Egypt? The nature of the current revolution, especially the social and political contexts in which it has taken place, promises transformative political changes; nevertheless, success in this respect is far from guaranteed. This is a revolution carried out by millions of common Egyptians against the military-supported, repressive political elites of the country. Instead of a foreign power, the revolution sought to oust local authoritarian rulers and their protégés. The first phase of the revolution has succeeded, while the second and more important phase - the building of democratic institutions and the creation of democratic norms and values- is yet in progress. The military council, the old and newly established political parties, the popularly elected parliament, and even the youth coalitions who were the driving force behind the revolution are yet to achieve the revolution's targets.

With the political parties and social groups arrayed across the political board, the military is still there. The military has ruled Egypt for the last six decades and is set to remain an integral part of the post-revolutionary political system for more than eighteen months until the elected president unseated it from power. The vast economic empire of the military and its political and administrative involvements cannot be easily displaced or replaced. The challenge for the postelections government and the new president include forging a balanced relationship with the military, a relationship acceptable to the democratic forces as well as the military establishment. Any attempt to damage military interests or marginalize it economically or politically may simply invite danger and destabilize the post-revolutionary political order.

The January Revolution has also facilitated and opened the door for the formation of new political parties, and removed restrictions on the Muslim Brotherhood and Salafi groups. The number political parties in Egypt have risen to approximately 60 . This inflation has created a confusing political situation in the Egyptian street and slowed down by complicating the democratization process. The parliamentary election conducted in 2011 was the first free election in Egyptian political history. However, due to the large number of parties and the short time allowed for election campaigning, the voting had a markedly random element to it. Subsequently, the parliament was dissolved in two months after it was elected.

\section{Conclusion}

Apparently, the primary push for democracy has come from the rival coalition of social and political forces; however, the youth coalition lacks unity. Other than the common goals of crushing autocracy and introducing democracy, the rival coalition of forces had no common threads tying them together - no nationally accepted leader, no common political ideology, and no dominant political party to oversee and guide post-revolutionary developments. Discord among the youth associations, the real driving force behind the revolution, is rather discouraging. The April 6 Youth Movement has pulled itself out of the Coalition of the Youth of the Revolution, an umbrella association of anti-Mubarak youth groups that successfully organized and sustained movements against Mubarak (Elyan, 2011). The youth coalition has not transformed itself into a new political party so far, and its prospects of doing so seem increasingly limited.

The youth did not develop a clear leadership structure capable of dealing with the changes and guiding the establishment of real democratic institutions. Unimportant issues have distracted them and led them to be scattered and divided into more than eighty more-or-less distinct groups. They are still arguing over their plans and on the necessity of having a road map to change. As a result, their popular support is diminishing. People have started to lose their patience and trust in them. An example of that is the growing reluctance of the Egyptians to respond to the revolutionists' call for civil disobedience, regardless of its targets.

During the first parliamentarian elections, youths kept protesting and striking in Tahrir Square without any evident political participation. Even their support for the liberal parties was fractured in nature. They were busy challenging the police and the military council, leaving the door opens to the agents of the opposing revolution to degrade the soft and hard powers of Egypt. Unfortunately, they did not play any active role in educating constituents. They left the stage to the political Islamists, who transformed the concept of the election to be as a choice between being an upstanding Islamist if you vote for them or an atheist if you do not. Because Egyptians have historically strong religious inclinations, they voted for the Islamist parties.

The Islamic group includes all the Islamic parties such as the Al-Noor (Salafi) and Al-Wasat parties. The Muslim Brotherhood, represented by their party "the Freedom and Justice," is the leader of this group. The Muslim Brotherhood, long suppressed by the three authoritarian regimes of the past, stands as the largest, most cohesive political opposition. Nevertheless, the Brotherhood leadership suffers from internal dissensions, with the old guards controlling the Guidance Council of the party and the vanguard of young leaders pushing for democratic changes in party decision-making structures. At one stage, the young leaders floated a new political party called 'Wasat' to champion a multiparty system, the establishment of the rule of law, and an end to military rule. The Mubarak government did not recognize the Wasat 
party. However, it has recently secured an official license to operate as a legal political party. Young Brotherhood leaders also form splinter political parties, such as the Renaissance Party and the Egyptian Renaissance Party (Phillips, 2011).Internal divisions within the Muslim Brotherhood will undercut its dominance at the national level in the long term, though it remains thebest organized socially and politically to launch a strong bid for political power.

Some religious groups, other than the Muslim Brotherhood, are gradual gaining importance in Egyptian politics, which the political liberals and secular forces view as a serious concern. The fundamentalist Islamic forces, called the Salafis, have recently drawn public attention by raising sectarian tensions and advocating the idea of an Islamic governance system in Egypt. They follow a literal interpretation of the Koran and stand for Sharia law (the Islamic legal system) as practiced by the Great Prophet of Islam and his four great companions in the seventh century (El-Hennawy, 2011). Until the revolution, the Salafis were primarily a mosque-based group with no distinct organizational structure or political platform. This group is more active in rural Egypt and is a marginal force at the national level. However, their political ideology is gradually creeping into Egyptian politics (Chick, 2011). In spite of the differences in the Islamic groups' ideologies, they all agree and focus on Islamizing the political, social, and economic systems. It is worth noting that the inability of the parliament controlled by Muslim Brotherhood to make changes until now in the state structure or governmental performance is raising many questions over its supposed ability to rule in the new political climate.

The liberal group includes several political parties from the middle and left wings. Some of these parties are new and have little political experience or popular support. They were established in a hurry after January's revolution. Some consider the Al-Wafd party as the leader of this group, since it is the oldest liberal party in Egypt. The Al-Wafd Party was in power for seven years during Egypt's so-called glorious liberal epoch (from 1923 to 1952). In the entire post-1952 period, the liberals languished in the opposition and won fewer parliamentary seats in the elections held under the different authoritarian regimes. In the changed political context, new liberal forces are emerging to vie for political power. The business tycoon Naguib Sawiris has launched a new political party - the Liberal Egyptians Party - to compete with the Muslim Brotherhood. Although liberal parties have different ideologies, they share the principle of the importance of the citizens' political rights, civil liberties, and social justice. These parties are adopting the ideology of a genuinely secular state. Egypt's political liberals, long active in the political field though still less dominant and less organized nationally are in the process of reorganizing. On the other hand, the trade unions played a significant role in the revolution but lack a national level political party to carry forward the spirit of the revolution.

The lively interplay of diverse political and social forces in post-revolutionary Egypt brings a number of important points to light. Firstly, it is remarkable that Egypt has made a clean break from its authoritarian past and is heading towards the path of democracy. The much-anticipated political changes are in the offing. A return to the authoritarian past is simply improbable in the post-democratic revolutionary context. Secondly, the rival coalition of social and political forces long controlled by the authoritarian rulers and the iron triangle gained the upper hand after February 11, 2011. In all likelihood, they will remain as the vanguard forces for democracy, despite lacking common purpose in many respects. Thirdly, the post-revolutionary political system is being characterized by clear directions for a multiparty system. The Islamists, the secularists, the liberals, the leftists and even the remnants of the now disbanded NDP are coexisting and attempting to compete. What is needed is the development of a tolerant political culture. If the political forces keep looking to the past, they will not be able to produce a firm democratic footing for Egypt. Fourthly, the military is and always has been a dominant part of Egyptian national life, and this fact needs to be well recognized by all political and social forces in Egypt.

To conclude, even Egypt's post-revolutionary social and political dynamics do instill much optimism for a successful transition to democracy, and the road ahead is definitely bumpy. The political shift in favor of the antiauthoritarian political and social forces has opened up a new chapter of democracy for Egypt. The absence of a clear roadmap to hold these political and social forces together through some institutional framework is a setback for the prodemocracy forces. The changed socio-political dynamics have not crystallized; however, it is clear that there will be no return to the past - the gloomy days of authoritarian rule. Despite all the apparent turmoil, the victory of the prodemocracy forces has changed Egypt forever, enforcing a transition to a democratic political and social order.

\section{References:}

Alterman, J.B. (2000 a). Egypt: Stable, but for How Long? The Washington Quarterly, vol. 23, no. 4, p. 108-109.

Alterman, J.B. (2000 b). Egypt: Stable, but for How Long? The Washington Quarterly, vol. 23, no. 4, p. 114.

Amr, P. (2011a). Mubarak's Phantom Presidency. Al Jazeera News, February 3, 2011. Information accessed: March 17, 2011.

Amr, P. (2011b). Why Egypt's Progressives Win. Al Jazeera News, February 10, 2011. Information accessed: March 17, 2011.

Aoude, I.G. (1994). From National Bourgeois Development to Infitah: Egypt 1952-1992. Arab Studies Quarterly, vol. 16, no. 1. 
Bernard L. (2002). The Arabs in History. London: Oxford University Press.

Brownlee, J. (2007). A New Generation of Autocracy in Egypt. Brown Journal of World Affairs, vol. XIV, no. 1, pp. 74-76.

Chick, K. (2011). Egypt violence heightens concern about growing Salafi role. Christian Science Monitor, May 10 issue.

El-Hennawy, N. (2011). Military-Salafi relations in Egypt raise questions. Al Masry AI Youm (Cairo), May 10 issue.

Elyan, T. (2011). April 6 Quits Revolution Youth Coalition, Calls for a New One. Daily News Egypt (Cairo), April 26 issue.

Hudson, N. C. (1977). Arab Politics: The Search for Legitimacy .New Haven: Yale University Press, 1977.

King, S.J. (2007). Sustaining Authoritarianism in the Middle East and North Africa. Political Science Quarterly, vol. 122, no. 3, 2007.

Palmer, M. (2007). The Politics of the Middle East. 2nd ed., (Thomson, USA, 2007), pp. 82-83.

Phillips, D. L. (2011). Talking to the Muslim Brotherhood of Egypt. Daily News Egypt (Cairo), March 30 issue, 2011.

Said, A. M. (2011). Reform and Revolution. Al-Ahram Weekly, issue no. 1044, 2011.

Stacher, J.A. (2004a). Parties Over: The Demise of Egypt's Opposition Parties. British Journal of Middle Eastern Studies, vol. 31, no. 2, p. 220.

Stacher, J.A. (2004b). Parties Over: The Demise of Egypt's Opposition Parties. British Journal of Middle Eastern Studies, vol. 31, no. 2, p.219

Weaver, M. (2003). Pharaohs-in-Waiting: Who will succeed Hosni Mubarak as the ruler of the world's most populous and important Arab country? The Atlantic Monthly, October 2003 issue, p. 5. 
